\title{
Performance Analysis of Doubly Fed Induction Generator Using Vector Control Technique
}

\author{
Aye Myat Thin ${ }^{*}$, Nang Saw Yuzana Kyaing ${ }^{* *}$ \\ Department of Electrical Power Engineering, Mandalay Technology University \\ Mandalay, Myanmar
}

\begin{tabular}{l} 
Article Info \\
\hline Article history: \\
Received Apr 28, 2015 \\
Revised Jul 12, 2015 \\
Accepted Jul 22, 2015 \\
\hline
\end{tabular}

Keyword:

Doubly fed induction generator, Modelling and simulation, Reactive power compensation Variable speed wind turbine Voltage source converter

\begin{abstract}
There are many solar power and wind stations installed in the power system for environmental and economic reasons. In fact, wind energy is inexpensive and the safetest among all sources of renewable energy, it has been recognized that variable speed wind turbine based on the doubly fed induction generator. It is the most effective with less cost and high power yield. This paper has chosen doubly fed induction generator for a comprehensive study of modelling, performance and analysing. DFIG wind turbine has to operate below and above synchronous speed which requires smooth transition mode change for reliable operation to be controlled to provide stability for the power system. Hence its performance depends on the generator itself and the converter operation and control system. This paper presents completed mathematical model of DFIG with its AC/DC/AC converter driven by DC machine. The rotor is considered fed by a voltage source converter whereas the stator is connected to the grid directly. The capacity of the wind power generation is $1.5 \mathrm{MW}$. The voltage rating and frequency for this system are $575 \mathrm{~V}, 50 \mathrm{~Hz}$. This paper show detailed model of DFIG.
\end{abstract}

Copyright (C) 2015 Institute of Advanced Engineering and Science. All rights reserved.

\section{Corresponding Author:}

Aye Myat Thin,

Department of Electrical Power Engineering, Mandalay Technology University,

Mandalay, Myanmar.

Email: ayemyatthin.mtuep@gmail.com

\section{INTRODUCTION}

The electric power generation using wind farm is subject to considerable attention in the world due to the increase of electricity demand and consumption, which led to the depletion of existing energy sources such as fossil fuels, coal, and oil. Wind power is environmentally economically acceptable and the safest source among renewable energy sources [1]. Large wind turbines can be operated at a constant speed or variable speed using different types of generators that can be either directly connected to the network or connected through a power electronic converter.

In recent years more development has been carried out to improve the performance of variable speed wind turbines to overcome the problem of the necessity to operate above, below, and through synchronous speed; as the result of this development the wind energy industry ended up with doubly-fed induction generator. Wind turbine generator which is the most efficient generator in wind energy conversion system. In fact, it is one of the most important generators in high-power applications; it is a form of threephase asynchronous machine with its rotor windings also connected to the grid through the power electronic converter [2]. Indeed, DFIG offers a number of features when it is compared with other generators: its ability to operate at $( \pm 30 \%)$ of synchronous speed, its converter has only to handle rotor circuit power, high efficiency, maximum power extracted, and independent extracted, and independent control of active and reactive powers. On other hand, DFIG has some disadvantages such as its sensitivity to unbalanced fault condition which can heat the stator winding hence reduce the machine lifetime. Furthermore limited range 
speed, control complicity, and the cost of maintenance due to slip rings assembly [3] are among its advantage.

In general, the control system of active and reactive power of DFIG is achieved by controlling the injectedrotor currents, using each of $d-q$ rotor currents to regulate the active and reactive powers independently of each other.

\section{WIND TURBINE MODELLING}

Wind turbines convert the kinetic energy present in the wind into mechanical energy by means of producing torque. Since the energy contained by the wind is in the form of kinetic energy, its magnitude depends on the air density and the wind velocity. The wind power developed by the turbine is given by the equation (1) [1-10]:

$$
\mathrm{P}_{\mathrm{m}}=\frac{1}{2} \mathrm{C}_{\mathrm{p}}(\lambda, \beta) \rho \mathrm{Av}^{3}
$$

Where $\mathrm{C}_{\mathrm{p}}$ is the Power Co-efficient, $\rho$ is the air density in $\mathrm{kg} / \mathrm{m}^{3} . \mathrm{A}$ is the area of the turbine blades in $\mathrm{m}^{2}$ and $\mathrm{V}$ is the wind velocity in $\mathrm{m} / \mathrm{sec}$. The power coefficient is defined as the power output of the wind turbine to the available power in the wind regime. This coefficient determines the "maximum power" the wind turbine can absorb from the available wind power at a given wind speed. It is a function of the tip-speed ratio $(\lambda)$ and the blade pitch angle $(\beta)$. The blade pitch angle can be controlled by using a "pitch-controller" and the tipspeed ratio (TSR) is given a

$$
\lambda=\frac{\omega \mathrm{R}}{\mathrm{v}}
$$

$\mathrm{P}_{\mathrm{m}=}$ Mechanical output power of the turbine $(\mathrm{W})$

$\mathrm{C}_{\mathrm{p}}=$ performance coefficient of the turbine

$\rho=$ the air density $\left(\mathrm{kg} / \mathrm{m}^{3}\right)$,

$\mathrm{A}=$ the turbine swept area $\left(\mathrm{m}^{2}\right)$,

$\mathrm{V}=$ wind speed $(\mathrm{m} / \mathrm{s})$

$\lambda=$ tip speed ratio of the rotor blade to wind speed and

$\beta=$ the blade pitch angle $(\mathrm{deg})$

Where $(\lambda)$ the rotational speed of the generator and R is is radius of the rotor blades. Hence, the TSR can be controlled by controlling the rotational speed of the generator. In a wind turbine, $\mathrm{C}_{\mathrm{p}}$ can be represented by a nonlinear curve in terms of $\lambda$ in place of different $\beta$ or the following relationship. [4]

$$
C_{p}=(0.44-0.016 \pi) \sin \left[\frac{\pi(\lambda-2)}{13-0.3 \beta}\right]-0.00184(\lambda-2) \beta
$$

\section{DOUBLY FED INDUCTION GENERATOR}

The DFIG is currently the system of choice for multi-MW wind turbines. The aerodynamic system must be capable of operating over a wide wind speed range in order to achieve optimum aerodynamic efficiency by tracking the optimum tip speed ratio. Therefore, the generator's rotor must be able to operate at a variable rotational speed. The DFIG system therefore operates in both sub- and super-synchronous modes with a rotor speed range around the synchronous speed.

The stator circuit is directly connected to the grid while the rotor winding is connected via slip-rings to a three-phase converter. For variable-speed systems where the speed range requirements are small, for example $\pm 30 \%$ of synchronous speed, the DFIG offers adequate performance and is sufficient for the speed range required to exploit typical wind resources an AC-DC-AC converter is included in the induction generator rotor circuit. The power electronic converters need only be rated to handle a fraction of the total power -the rotor power typically about $30 \%$ nominal generator power. Therefore, the losses in the power electronic converter can be reduced, compared to a system where the converter has to handle the entire power, and the system cost is lower due to the partially-rated power electronics. 


\section{OPERATING MODES OF DOUBLY FED INDUCTION GENERATOR}

The DFIG stator is connected to the grid with fixed grid frequency $\left(f_{S}\right)$ at fixed grid voltage $\left(V_{S}\right)$ to generate constant frequency. AC Power during all operating conditions and the rotor is connected to the frequency converter/VSC having a variable (slip/rotor) frequency $\left(f_{r}=s f_{S}\right)$. At constant frequency $f_{S}$, the magnetic field produced in the stator rotates at constant angular velocity/speed $\left(\omega_{\mathrm{S}}=2 \pi \mathrm{f}_{\mathrm{S}}\right)$, which is the synchronous speed of the machine. The stator rotating magnetic field will induce a voltage between the terminals of the rotor. This induced rotor voltage produces a rotor current $\left(\mathrm{I}_{\mathrm{r}}\right)$, which in turn produces a rotor magnetic field that rotates at variable angular velocity/speed $\left(\omega_{\mathrm{r}}=2 \pi \mathrm{f}_{\mathrm{r}}\right)$. Usually the stator and rotor have the same number of poles $(P)$ and the convention is that the stator magnetic field rotates clockwise. Therefore, the stator magnetic field rotates clockwise at a fixed constant speed of $\omega_{\mathrm{S}}(\mathrm{rpm})=120 \mathrm{f}_{\mathrm{S}} / \mathrm{P}$. Since the rotor is connected to the variable frequency VSC, the rotor magnetic field also rotates at a speed of $\omega_{\mathrm{r}}(\mathrm{rpm})=120 \mathrm{f}_{\mathrm{r}} / \mathrm{P}$.

\subsection{Sub-Synchronous Speed Mode}

Figure 1 illustrates the case where the rotor magnetic field rotates at a slower speed than the stator magnetic field.

The machine is operated in the sub-synchronous mode, i.e. $\omega_{\mathrm{m}}\left\langle\omega_{\mathrm{S}}\right.$

1. If and only if its speed is exactly $\omega_{\mathrm{m}}=\omega_{\mathrm{s}}-\omega_{\mathrm{r}}>0$ and

2. Both the phase sequences of the rotor and stator mmf's are the same and in the positive direction, as referred to as positive phase sequence $\left(\omega_{\mathrm{r}}>0\right)$. This condition takes place during slow wind speeds. In order to extract maximum power from the wind turbine, the following conditions should be satisfied:

3. The rotor side VSC shall provide low frequency AC current (negative $\mathrm{v}_{\mathrm{r}}$ will apply) for the rotor winding.

4. The rotor power shall be supplied by the DC bus capacitor via the rotor side VSC, which tends to decrease the DC bus voltage. The grid side VSC increases/controls this DC voltage and tends to keep it constant. Power is absorbed from the grid via the grid side VSC and delivered to the rotor via the rotor side VSC. During this operating mode, the grid side VSC operates as a rectifier and rotor side VSC operates as an inverter. Hence power is delivered to the grid by the stator.

5. The rotor power is capacitive.

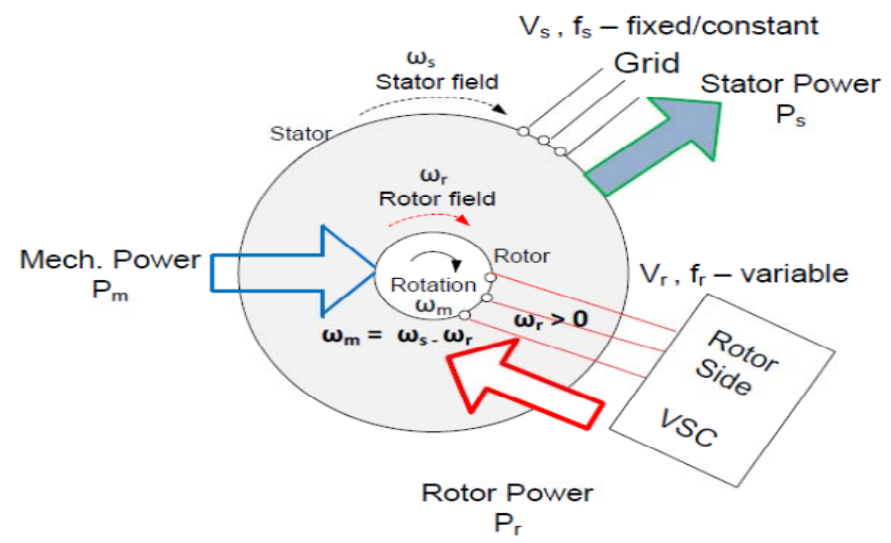

Figure 1. Sub-synchronous operating mode of DFIG

\subsection{Super-Synchronous Speed Mode}

The super-synchronous speed mode is achieved by having the rotor magnetic field rotate counter clockwise. Figure 2 represents this scenario. However, in order to represent the counter clockwise rotation of the rotor, which is analytically equivalent to inverting the direction of the rotor magnetic field 


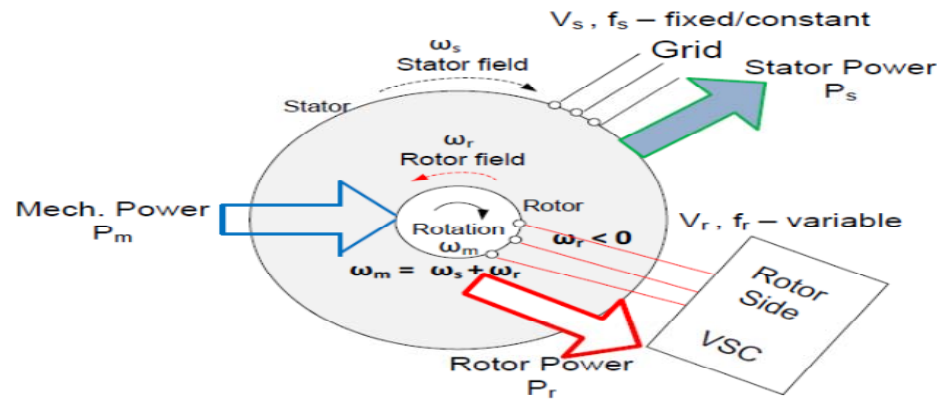

Figure 2. Super-synchronous operating mode of DFIG

The machine is operated in the super-synchronous mode, i.e., $\left.\omega_{\mathrm{m}}\right\rangle \omega_{\mathrm{s}}$

1. If and only if its speed is exactly $\omega_{\mathrm{m}}=\omega_{\mathrm{s}}-\left(-\omega_{\mathrm{r}}\right)=\omega_{\mathrm{s}}+\omega_{\mathrm{r}}>0$ (and

2. The phase sequence in the rotor rotates in opposite direction to that of the stator, i.e., negative phase sequence $\left(\omega_{\mathrm{r}}<0\right)$. This condition takes place during the condition of high wind speeds. The following conditions need to be satisfied in order to extract maximum power from the wind turbine and to reduce mechanical stress:

3. The rotor winding delivers AC power to the power grid through the VSCs.

4. The rotor power is transmitted to DC bus capacitor, which tends to raise the DC voltage. The grid side VSC reduces/controls this DC-link voltage and tends to keep it constant. Power is extracted from the rotor side VSC and delivered to the grid. During this operating mode, the rotor side VSC operates as a rectifier and the grid side VSC operates as an inverter. Hence power is delivered to the grid directly by the stator and via the VSCs by the rotor.

5. The rotor power is inductive

\subsection{Synchronous Speed Mode}

The synchronous speed mode is represented by figure 3 .

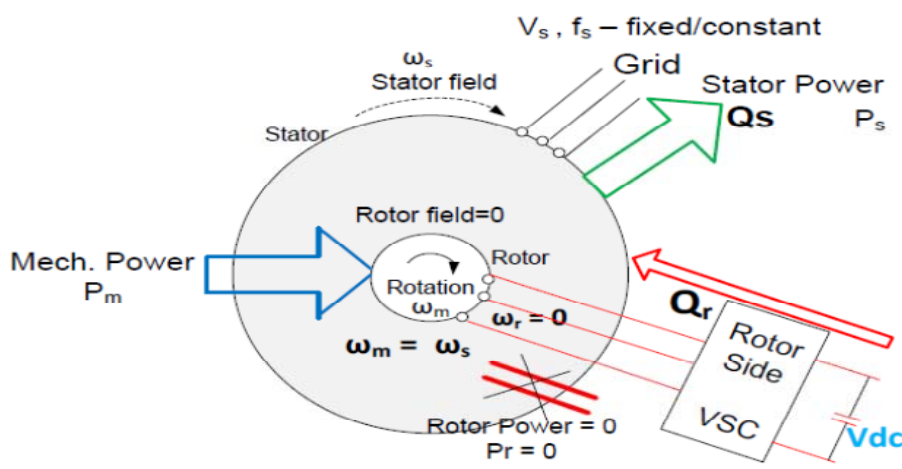

Figure 3. Synchronous operating mode of DFIG

The machine is operated in the synchronous speed mode, i.e. $\omega_{\mathrm{m}}=\omega_{\mathrm{s}}$

1. If and only if its speed is exactly $\omega_{\mathrm{m}}=\omega_{\mathrm{S}}-0=\omega_{\mathrm{S}}>0$, and

2. The phase sequence in the rotor is the same as that of the stator, but no rotor $\mathrm{mmf}$ is produced $\left(\omega_{\mathrm{r}}=0\right)$. The following conditions are necessary in order to extract maximum power from the wind turbine under this condition:

3. The rotor side converter shall provide DC excitation for the rotor, so that the generator operates as a synchronous machine. The rotor side VSC will not provide any kind of AC current/power for the rotor winding. Hence the rotor power is zero $\left(\mathrm{P}_{\mathrm{r}}=0\right)$.

Generator can generate in both sub and super synchronous mode, here the speed is taken as super synchronous speed, where the power can be extracted from the stator as well as rotor circuit. The machines 
use two back to back converters in the rotor circuit. The main purpose of the machine side converter is to controls the active and reactive power by controlling the $\mathrm{d}$-q components of rotor current while the grid-side converter is to control the dc link voltage and ensures the operation at unity power factor by making the reactive power drawn by the system from the utility grid to zero.

\section{MODELLING OF DOUBLY FED INDUCTION GENERATOR}

The doubly fed induction generator has been used for variable speed drives. The stator is connected directly to the grid and the rotor is fed by a bidirectional converter that is also connected to the grid. Using vector control techniques, the bidirectional converter assures energy generation at nominal grid frequency. The converter's main aim is to compensate for the difference between the speed of the rotor and the synchronous speed with the slip control

The main characteristics may be summarized as follows:

i. limited operating speed range $(-30 \%$ to $+20 \%)$

ii. Small scale power electronic converter (reduced power losses and price)

iii. Complete control of active power and reactive power exchanged with the grid

a. Need for slip-rings

b. Need for gearbox (normally a three-stage one

For a DFIG associated with a back-to-back converter on the rotor side and with the stator directly connected to the grid, an SFOC (stator flux oriented control) system is used in order to control separately the active and reactive power on the stator side.

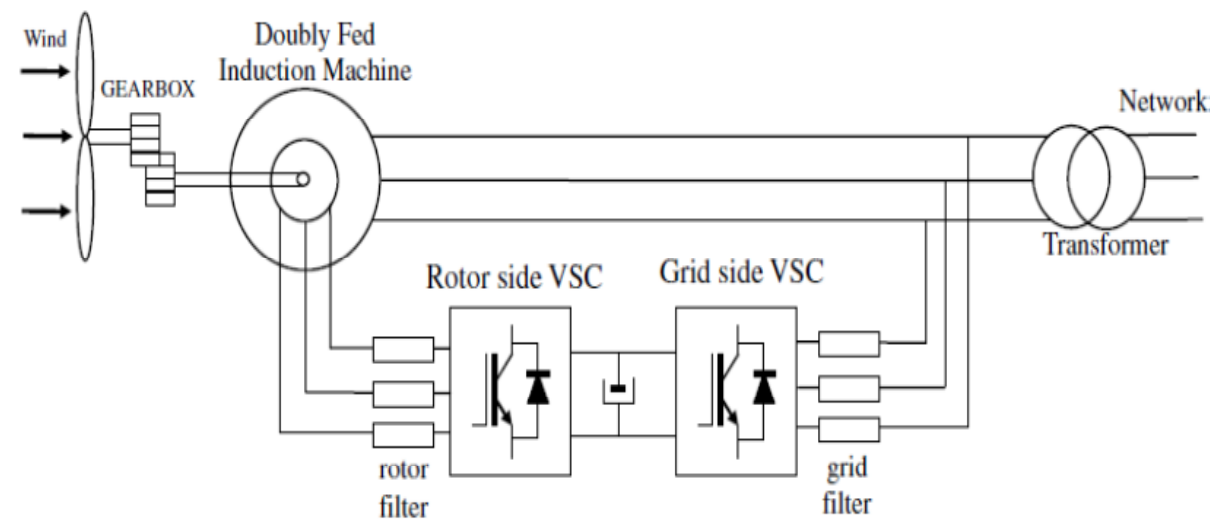

Figure 4. Doubly fed induction machine based wind turbine

\section{DYNAMIC SIMULATION OF DFIG IN TERMS OF DQ WINDINGS}

The dynamic performance of ac machine is somewhat complex because the three phase rotor windings move with respect to three phase stator windings. Hence a three phase machine can be represented with an equivalent two phase machine replacing the variables associated with the stator windings of a machine with variables associated with fictious windings rotating with the rotor at synchronous speed. The analysis can be simplified greatly by transforming the three phase stator and rotor windings (with angular displacement) to a fictious two phase stator and rotor. These fictious two phase windings are called d-q windings. The stators and rotor a-, b- and c-phase voltage equations can be transformed to the d-q axis. It is needed to consider the following three facts if the model of doubly fed induction generator creat.They are

1. Transformation of 3 stationary to 2 stationary axes

2. Transformation of 2 stationary to 2 synchronously axes

3. Mathematical model of doubly fed induction generator

$$
\begin{aligned}
& \mathrm{V}_{\mathrm{ds}}=\mathrm{R}_{\mathrm{s}} \mathrm{i}_{\mathrm{ds}}+\frac{\mathrm{d} \varphi_{\mathrm{ds}}}{\mathrm{dt}}-\omega_{\mathrm{s}} \varphi_{\mathrm{qs}} \\
& \mathrm{V}_{\mathrm{qs}}=\mathrm{R}_{\mathrm{s}} \mathrm{i}_{\mathrm{qs}}+\frac{\mathrm{d} \varphi_{\mathrm{qs}}}{\mathrm{dt}}+\omega_{\mathrm{s}} \varphi_{\mathrm{ds}}
\end{aligned}
$$




$$
\begin{aligned}
& \mathrm{V}_{\mathrm{dr}}=\mathrm{R}_{\mathrm{r}} \mathrm{i}_{\mathrm{dr}}+\frac{\mathrm{d} \varphi_{\mathrm{dr}}}{\mathrm{dt}}-\left(\omega_{\mathrm{s}}-\omega_{\mathrm{r}}\right) \varphi_{\mathrm{qr}} \\
& \mathrm{V}_{\mathrm{qr}}=\mathrm{R}_{\mathrm{r}} \mathrm{i}_{\mathrm{qr}}+\frac{\mathrm{d} \varphi_{\mathrm{qr}}}{\mathrm{dt}}+\left(\omega_{\mathrm{s}}-\omega_{\mathrm{r}}\right) \varphi_{\mathrm{dr}}
\end{aligned}
$$

The stator flux can be expressed as:

$$
\begin{aligned}
& \varphi_{\mathrm{ds}}=\mathrm{L}_{\mathrm{s}} \mathrm{i}_{\mathrm{ds}}+\mathrm{L}_{\mathrm{m}} \mathrm{i}_{\mathrm{dr}} \\
& \varphi_{\mathrm{qs}}=\mathrm{L}_{\mathrm{s}} \mathrm{i}_{\mathrm{qs}}+\mathrm{L}_{\mathrm{m}} \mathrm{i}_{\mathrm{qr}}
\end{aligned}
$$

The rotor flux can be expressed as

$$
\begin{aligned}
& \varphi_{\mathrm{dr}}=\mathrm{L}_{\mathrm{r}} \mathrm{i}_{\mathrm{dr}}+\mathrm{L}_{\mathrm{m}} \mathrm{i}_{\mathrm{ds}} \\
& \varphi_{\mathrm{qr}}=\mathrm{L}_{\mathrm{r}} \mathrm{i}_{\mathrm{qr}}+\mathrm{L}_{\mathrm{m}} \mathrm{i}_{\mathrm{qs}}
\end{aligned}
$$

The active and reactive power at the stator

$$
\begin{aligned}
& \mathrm{P}_{\mathrm{s}}=\mathrm{v}_{\mathrm{ds}} \mathrm{i}_{\mathrm{ds}}+\mathrm{v}_{\mathrm{qs}} \mathrm{i}_{\mathrm{qs}} \\
& \mathrm{Q}_{\mathrm{s}}=\mathrm{V}_{\mathrm{qs}} \mathrm{i}_{\mathrm{ds}}-\mathrm{V}_{\mathrm{ds}} \mathrm{i}_{\mathrm{qs}}
\end{aligned}
$$

The active and reactive power at the rotor

$$
\begin{aligned}
& \mathrm{P}_{\mathrm{r}}=\mathrm{v}_{\mathrm{dr}} \mathrm{i}_{\mathrm{dr}}+\mathrm{v}_{\mathrm{qr}} \mathrm{i}_{\mathrm{qr}} \\
& \mathrm{Q}_{\mathrm{r}}=\mathrm{V}_{\mathrm{qr}} \mathrm{i}_{\mathrm{dr}}-\mathrm{V}_{\mathrm{dr}} \mathrm{i}_{\mathrm{qr}}
\end{aligned}
$$

In the area of wind energy production, machines of medium and high power which are mainly used. Thus, the stator resistance was neglected. By using the stator flux oriented principle, the stator flux is oriented on the d-axis, then the flux q-axis component

$$
\begin{aligned}
& \varphi_{\mathrm{qs}}=0 \\
& \varphi_{\mathrm{ds}}=\varphi_{\mathrm{s}}
\end{aligned}
$$

Hence, the stator voltage can be written as

$$
\begin{aligned}
& \mathrm{V}_{\mathrm{ds}}=0 \\
& \mathrm{~V}_{\mathrm{qs}}=\left|\mathrm{V}_{\mathrm{s}}\right|=\omega \varphi_{\mathrm{ds}} \\
& \mathrm{i}_{\mathrm{qs}}=\frac{-\mathrm{L}_{\mathrm{m}}}{\mathrm{L}_{\mathrm{s}}} \mathrm{i}_{\mathrm{qr}}
\end{aligned}
$$




$$
\begin{aligned}
& \mathrm{P}_{\mathrm{s}}=\frac{3}{2}\left(\mathrm{v}_{\mathrm{ds}} \mathrm{i}_{\mathrm{ds}}+\mathrm{v}_{\mathrm{qs}} \mathrm{i}_{\mathrm{qs}}\right) \\
& \mathrm{Q}_{\mathrm{s}}=\frac{3}{2}\left(\mathrm{v}_{\mathrm{qs}} \mathrm{i}_{\mathrm{ds}}-\mathrm{v}_{\mathrm{ds}} \mathrm{i}_{\mathrm{qs}}\right) \\
& \mathrm{P}_{\mathrm{s}}=-\frac{3}{2}\left|\mathrm{v}_{\mathrm{s}}\right| \frac{\mathrm{L}_{\mathrm{m}}}{\mathrm{L}_{\mathrm{s}}} \mathrm{qr} \\
& \mathrm{P}_{\mathrm{r}}=\mathrm{sV}_{\mathrm{s}} \frac{\mathrm{L}_{\mathrm{m}}}{\mathrm{L}_{\mathrm{s}}} \mathrm{i}_{\mathrm{rq}} \\
& \mathrm{Q}_{\mathrm{r}}=\mathrm{sV}_{\mathrm{s}} \frac{\mathrm{L}_{\mathrm{m}}}{\mathrm{L}_{\mathrm{s}}} \mathrm{i}_{\mathrm{rd}}
\end{aligned}
$$

\section{TECHNICAL DATE FOR GENERATOR AND CONVERTER}

Doubly fed induction generator needs the following parameter. They are generator data, converter data and other parameters.

Table 1. Parameters of generator

\begin{tabular}{cc}
\hline Nominal Power & $1.5 \mathrm{MW}$ \\
Line to line voltage & $575 \mathrm{~V}$ \\
Frequency $(\mathrm{f})$ & $50 \mathrm{~Hz}$ \\
Stator Resistance $\left(\mathrm{R}_{\mathrm{s}}\right)$ & $0.023 \mathrm{pu}$ \\
Rotor Resistance $\left(\mathrm{R}_{\mathrm{r}}\right)$ & $0.016 \mathrm{pu}$ \\
Magnetizing Inductance $\left(\mathrm{L}_{\mathrm{m}}\right)$ & $2.9 \mathrm{pu}$ \\
\hline & \\
Table 2. Parameter of grid & \\
\hline Max. Power & $0.5 \mathrm{pu}$ \\
Grid-side coupling inductor $(\mathrm{L}, \mathrm{R})$ & $0.3 \mathrm{pu}, 0.003 \mathrm{pu}$ \\
Nominal DC bus voltage & $1150 \mathrm{~V}$ \\
DC bus capacitor & $10000 \mathrm{e}-6$ \\
\hline
\end{tabular}

Doubly-fed induction generator also has control regulator gains, DC bus voltage regulator gains and rotor side current regulator gains.

\section{DETAILED MODEL FOR DOUBLY FED INDUCTION GENERATOR}

A $1.5 \mathrm{MW}$ wind farm connected to a $25-\mathrm{kV}$ distribution system exports power to a $230-\mathrm{kV}$ grid through a $30 \mathrm{~km} 25 \mathrm{kV}$ feeder. $400-\mathrm{kW}$ resistive load is connected on the induction generator (DFIG) consisting of a wound rotor induction generator and an AC/DC/AC IGBT-based PWM converter. Wind turbines use a doubly-fed induction generator. 


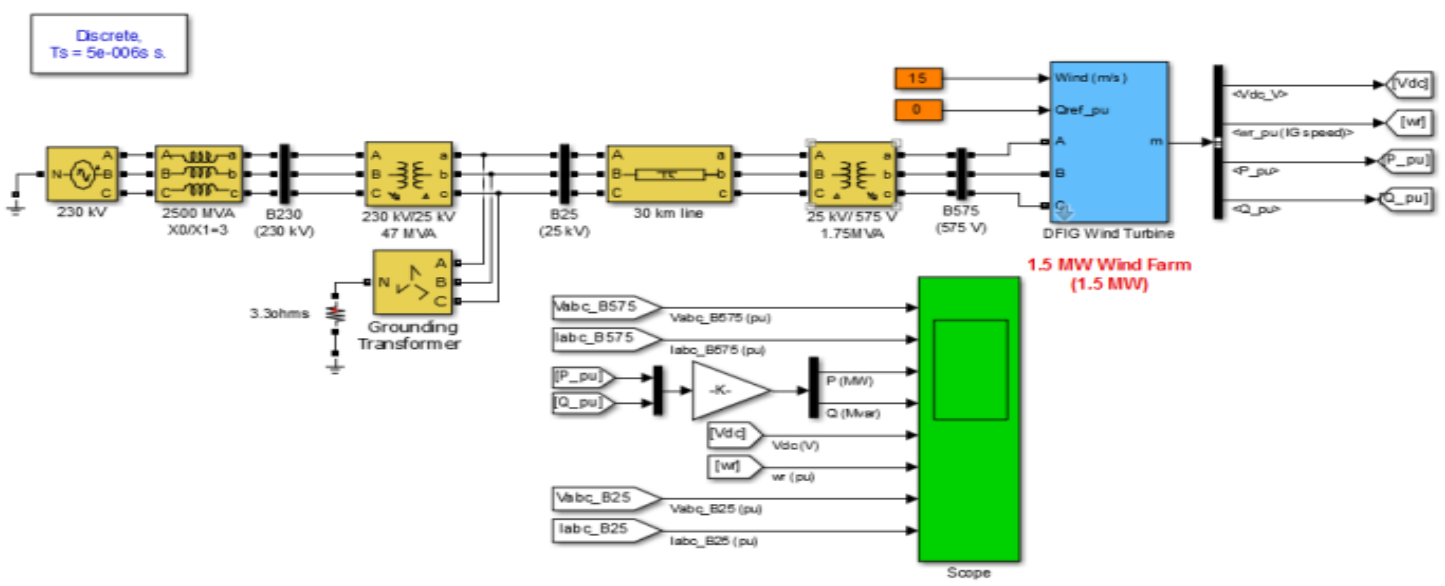

Figure 5. Wind Farm DFIG Detailed Model

The stator winding is connected directly to the $50 \mathrm{~Hz}$ grid while the rotor is fed at variable frequency through the AC/DC/AC converter. The DFIG technology allows extracting maximum energy from the wind for low wind speeds by optimizing the turbine speed, while minimizing mechanical stresses on the turbine during gusts of wind. In this model, the wind speed is maintained constant at $15 \mathrm{~m} / \mathrm{s}$. The control system uses a torque controller in order to maintain the speed at $1.2 \mathrm{pu}$. The reactive power produced by the wind turbine is regulated at $0 \mathrm{Mvar}$.

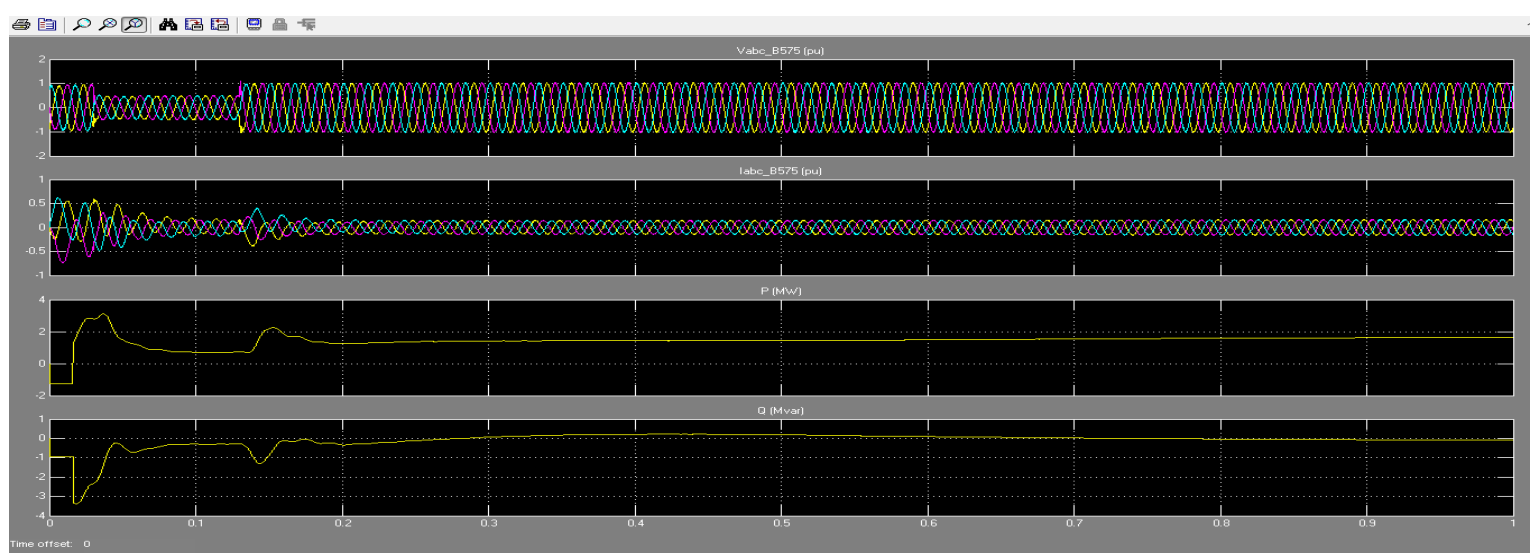

Figure 6. Simulation results of rated power, reactive power, voltage and current 


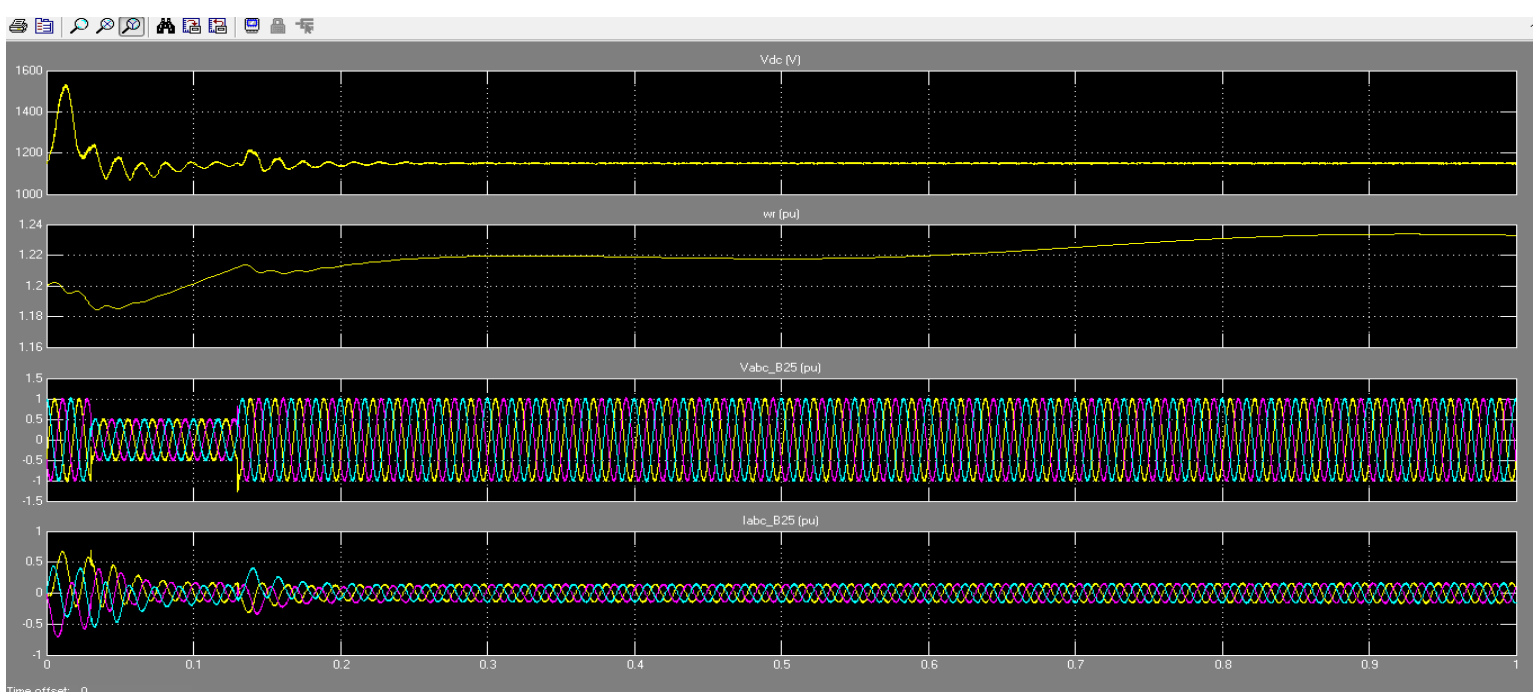

Figure 7. Simulation results of DC bus voltage, turbine speed, voltage and current

\section{SIMULATION RESULTS OF 1.5MW WIND FARM CONNECTED TO GRID}

Initially the DFIG wind firm produces active power of $1.5 \mathrm{MW}$ which corresponds to maximum mechanical turbine output minus electrical losses generator. When the grid voltage changes suddenly from its rated value 575 the stator current increases and the active power P suddenly oscillates and then it settles to its rated value.The reference reactive power is set at 0Mvar but when voltage decreases the reactive power suddenly increases then it settles to 0Mvar as per the control strategy made in the rotor side converter. The dc link voltagew is swet at $1150 \mathrm{~V}$ by the grid side converter but at the time of voltage sag it oscillates and finally settles to its set value and the rotor speed is also maintained constant to its rated while the wind speed is kept constant at $15 \mathrm{~m} / \mathrm{s}$. The turbine speed is $1.2 \mathrm{pu}$ of generator synchronous speed.The DC voltage is regulated at $1150 \mathrm{~V}$ and reactive power is kept at 0 Mvar.At $\mathrm{t}=0.03 \mathrm{~s}$, the positive sequence voltage suddenly drops to $0.5 \mathrm{pu}$ causing an oscillation on the DC bus voltage and on the DFIG output power.During the voltage sag control system tries to regulate $\mathrm{DC}$ voltage and reactive power at their set points.

\section{CONCLUSION}

The performance analysis of a doubly-fed induction generator driven by a wind turbine has been described. In this paper, dynamic equation of doubly fed induction generator has been shown. Especially, Generated power, DC voltage, wind speed, pitch angle and grid side voltages are identified by using MATLAB simulation model. Due to the advances in power electronics, it advantaged to use the doubly fed induction generator system with variable speed connected to the electrical grid through an AC-DC-AC converter for improving the efficiency of the power conversion. The DFIG is able to provide a considerable contribution to grid voltage support during short circuit periods. Considering the results it can be said that DFIG proved to be more reliable and stable system when connected to grid side with the proper converter control systems.Due to the above this control system, the result will give the optimal condition for the overall generation. It is certain that the advertence technology and knowledge of grid connected DFIG wind turbine generating system can be got from this paper.

\section{ACKNOWLEDGEMENTS}

First of all, the author is grateful to express her deepest gratitude to His Excellency Dr Yan Aung Oo., Professor and Head of Department of Electrical power Engineering, Mandalay Technological University, for his encouragement, constructive guidance and kindly advice throughout the preparation of this paper.

The author especially indebted and grateful to supervisor Dr. Nang Saw Yuzana Kyaing, lecturer, Department of Electrical Engineering, Mandalay Technological University, for her encouragement, valuable supervision, suggestions, kindly permission and guideline during the entire course for the preparation of this paper.

And the author would like to convey her gratitude to all persons who were directly or indirectly involved towards the successful completion of this paper.

Performance Analysis of Doubly Fed Induction Generator Using Vector Control Technique (Aye Myat Thin) 
REFERENCES

[1] "DFIG Based Wind Power Conversion System Connected To Grid" International Journal of Technical Research and Applications Vol. 1, Issue 3 (July-August 2013)

[2] Modelling and Control of a DFIG-Based Wind Turbine During a Grid Voltage Drop" ETASR Engineering, Technology \& Applied Science Research, Vol. 1, No.5, 2011, 121-125

[3] "Modelling and Simulation of Doubly Fed Induction Generator Coupled With Wind Turbine-An Overview" Journal of Engineering, Computers \& Applied Sciences (JEC\&AS), Vol 2, No.8, August 2013

[4] Department of Meteorology and Hydrology, “Assessment of Solar Energy Potentials for Myanmar", September 2009.

[5] "Performance Analysis of Doubly Fed Induction Generator in Wind Energy Conversion System", ODISHA, INDIA, June 2011

[6] "Performance of Control Dynamic of Wind Turbine Based on Doubly Fed Induction Generator under Different Modes of Operation, A.A. Mohammed, Electrical and electronic engineering department, university of Benghazi, Elmarj, Libya

[7] Analysis, Modelling and Control of Doubly Fed Induction Generator", Division of Electric Power Engineering, Department of Energy and Environment, Chalmers university of Technology,Gotehory Sweden 2005.

[8] Vector Control of a Doubly Fed Induction Generator based Wind Turbine

[9] Grid Connected Doubly Fed Induction Generator Based Wind Turbine under Low Voltage Ride Through, Department of Electric, Electronic and Information Engineering,GUGLELMO MARCONIS, March 2014,Bologna,Italy

[10] “A Vector Controlled of Doubly Fed Induction Generator for a Variable Speed Wind Turbine Application", by D.J Atkinson A. akin and R. Jones, 1997

[11] "Modelling, Control and Analysis of a Doubly Fed Induction Generator Based Wind Turbine Systems with Voltage Regulation"

\section{BIOGRAPHIES OF AUTHORS}

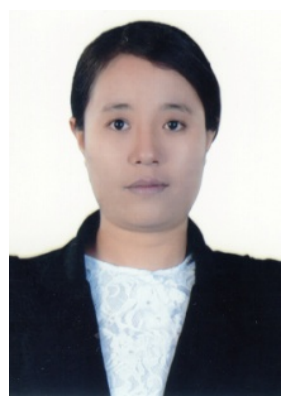

Ms. Aye Myat Thin. She was born on $19^{\text {th }}$ August 1984. She got the BE degree and ME degree in Electrical Power Engineering from Technological University (Mandalay), Myanmar. And she is also working as an assistant lecturer at Technological University (Mandalay). Now, she is attending Ph.D degree in Electrical Power in Mandalay Technological University, Myanmar. She achieved ICSE paper that held in Inyar Lake hotel and International paper from ICTAEECE Conference that held in Bangkok during this year. Her main interest is in Renewable Energy and Power Electronics. Her email is ayemyatthin.mtuep@gmail.com.

Nang Saw Yuzana Kyaing, Department of Electrical Power Engineering, Mandalay Technology University, Mandalay, Myanmar. Email: nansawyuzana@gmail.com 